\title{
Social isolation at weaning: Some effects on two measures of activity*
}

\author{
LESLEY A. SYME† \\ University of Canterbury, Christchurch, New Zealand
}

\begin{abstract}
Both the age at which housing conditions are imposed and the type of activity measured are shown to affect the results obtained in studies concerned with the effects of social density on the behavior of laboratory rats.
\end{abstract}

In a review of the effects of population density in the cage environment upon the later activity of laboratory rodents, Archer (1970) notes that many of the studies have produced conflicting results. While some investigations have shown isolates to be less active than grouped animals in a novel test situation (Stern, Winokur, Eisenstein, Taylor, \& Sly, 1960; Moyer \& Korn, 1965; Archer, 1969), others have shown the reverse to be true (Essman, 1966; Weltman, Sackler, \& Sparber, 1966). Syme and Hughes (1972) and Syme ${ }^{1}$, in two studies comparing the activity of isolated and grouped rats, suggested several reasons for these discrepancies. Firstly, cage size of isolated animals was shown to affect activity in the open field, and secondly, it was demonstrated that rats and mice should be considered separately since activity differences arising from grouped and isolated housing conditions are opposite for the two species within 1 day of weaning. There are, however, a number of other contributing variables, two of which are investigated in this study.

It is possible that the age at which housing conditions are introduced is important. Bronfenbrenner (1968) suggests that the effects of stimulus deprivation are negatively related to the age at which such deprivation occurs. The present experiment was designed primarily to investigate the effect of imposing different housing conditions at weaning rather than at some later time. In contrast to Archer (1969), who isolated female rats at 40 days of age and compared their activity with that of grouped animals 24 weeks later, this study used female rats isolated at weaning and tested them after the same period in comparison with control-grouped and crowded animals. Adrenal weights, as a supplementary index of social stress (Schnürer, 1963; Barnett, 1964), were obtained after 3 and 6 months. Two measures of activity are used. Locomotor activity was observed in an open field, while nonspecific general activity was measured on an activity platform. This provides a test of the prevalent assumption (Baumeister, Hawkins, \& Cromwell, 1964) that the different methods can be regarded as equivalent when comparisons of activity studies are made.

*I thank Dr. R. N. Hughes and G. J. Syme for their help in the preparation of this paper. The teclinical assistance of Robynne $S$. Moore in the adrenal preparations is gratefully acknowledged.

† Present address: Ruakura Animal Research Station. Hamilton, New Zealand.

\section{METHOD}

\section{Subjects and Apparatus}

The Ss were 74 female hooded rats (N.Z.B.W.S. $)^{2}$ weaned and differentially housed at 23 days of age. Twenty-six rats were isolated in cages measuring $18 \times 18 \times 18 \mathrm{~cm}$ high, while six groups of 8 animals each were housed in cages measuring $75 \times 45$ $x 33 \mathrm{~cm}$ high. Ad lib food and water were provided, and the animals were maintained on a reversed light-dark schedule from 7 p.m. to $7 \mathrm{a} . \mathrm{m}$. Cages were cleaned once a week, and the animals were not otherwise handled. At 120 days of age (approximately 14 wecks later), 6 rats from each cage condition were weighed, sacrificed, and their adrenal glands removed and weighed to the nearest milligram. Because it was considered desirable to test all animals directly from their home cage (Kinnard \& Watzman. 1972; Syme \& Syme, 1973) to avoid socially isolating the group-housed animals prior to testing. the grouped animals were rehoused in easily transportable cages at this stage. Three groups of 7 rats each were caged in crowded conditions in cages measuring $30 \times 30 \times 20 \mathrm{~cm}$ high, and another two groups of 7 rats were housed in cages measuring $50 \times 35 x$ $30 \mathrm{~cm}$ high (control). Rehousing of the Ss thus necessitated the removal of 7 animals from the experiment. When the animals were 190 days old and had been in their respective cage conditions for a further 10 weeks, 6 isolated and 6 crowded animals were weighed, then sacrificed, and the adrenal glands removed and weighed to the nearest milligram. One crowded animal was similarly discarded from the experiment at this point. Three groups of 7 rats from the three cage conditions (isolated. control-grouped. and crowded) were tested in an open field measuring $60 \times 60 \times 20 \mathrm{~cm}$ high. The floor of the apparatus was marked out into $15 \times 15 \mathrm{~cm}$ squares and was illuminated by a 40-W fluorescent lamp suspended $75 \mathrm{~cm}$ above it. The number of squares crossed by the back legs of each animal during a 10-min period was recorded. The other, as yet untested, three groups of animals (isolated, control-grouped, and crowded) were tested individually on a similarly illuminated Lafayette A501 activity platform for $5 \mathrm{~min}$ each. All testing occurred between $9 \mathrm{a} . \mathrm{m}$. and 4:30 p.m., and approximately $40 \mathrm{~dB}$ of white noise provided an auditory masking background during this time.

\section{RESULTS}

Because the variances of the behavioral measures for the particular groups proved to be significantly different, using the Hartley test for homogeneity of variance (Winer, 1962), nonparametric tests were used to analyze the data. The median activity scores obtained by the three groups of animals in the open field (number of squares crossed) and on the activity platform are shown in Table 1 and the relationships between these in Fig. 1 . In the open field. both isolated and crowded rats crossed 
Table 1

Median Activity Scores for Isolated, Control, and Crowded Female Rats in Both the Open Field Number of Squares Crossed) and the Activity Platform

\begin{tabular}{lccc}
\hline & \multicolumn{3}{c}{ Density } \\
\cline { 2 - 4 } & $\begin{array}{c}\text { Isolated } \\
(\mathrm{N}=7)\end{array}$ & $\begin{array}{c}\text { Control } \\
(\mathrm{N}=7)\end{array}$ & $\begin{array}{c}\text { Crowded } \\
(\mathrm{N}=7)\end{array}$ \\
\hline Open Field & $182^{*}$ & 130 & $181^{*}$ \\
Activity Platform & 800.5 & 764 & $890^{*}$ \\
\hline
\end{tabular}

*Differs significantly from control group $(p<.05$, Mann. W'hitney $U^{\prime}$ test): other comparisons not significant.

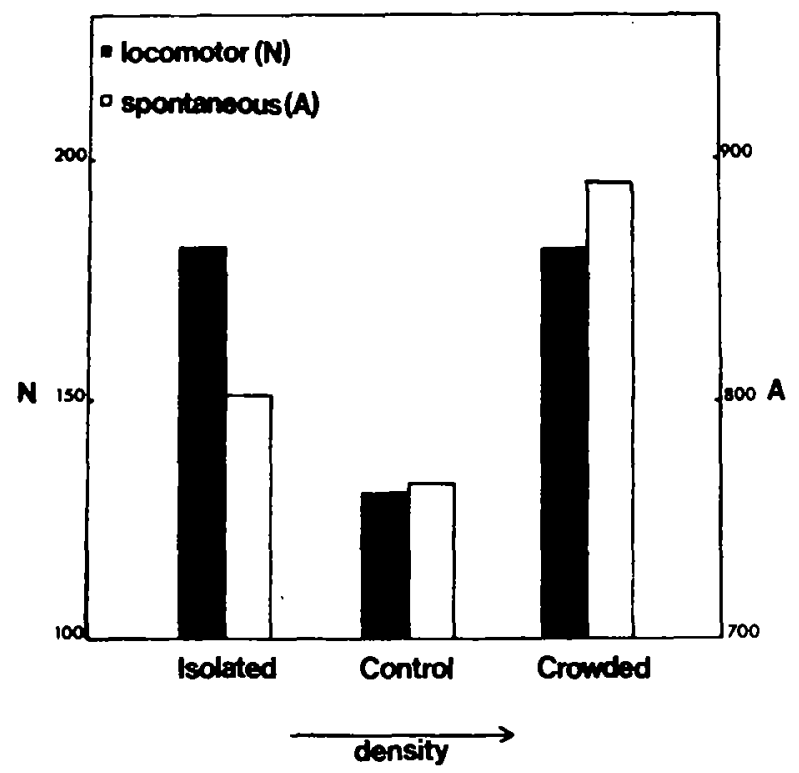

Fig. 1. Relationship between locomotor $(N)$ and nonspecific general "spontaneous" activity (A) exhibited by Ss in the open field and on the activity platform.

significantly more squares during the 10-min test period than did the control-grouped animals, while there was no significant difference between the two groups. Using the activity platform, the crowded rats were significantly more active than the control-grouped animals but were not significantly more active than the isolates. There was no significant difference between the isolated and control-grouped animals on this activity measure. Table 2 shows the body and adrenal weights measured when the animals were 120 and 190 days of age. After 14 weeks of differential housing, using the $t^{\prime}$ test for unequal population variances (Winer, 1962), the mean relative weight of the adrenals of the isolated rats was significantly heavier than that of the control group-housed animals, as was also the absolute weight of these organs. Ten weeks later, the isolated rats still had heavier adrenals (relative and absolute weights) than those of the grouped-crowded animals, although the difference was not a significant one. There was no significant change in the absolute weights of these organs between the two periods for either isolated or grouped-crowded animals. After 14 weeks of differential housing, the mean body weight of the isolated animals was significantly heavier than that of the group-housed animals. Ten week later, there were no significant differences in the body weights of the three groups of animals.

\section{DISCUSSION}

The results show that the introduction of differential housing conditions at weaning rather than at 40 days of age produces activity differences in the opposite direction to those found by Archer (1969); isolated female rats were more active than control-grouped animals in the open field. In that isolated rats are supposed to show greater emotionality and diminished exploratory behavior in such a novel test situation (Archer, 1970), this is an interesting result. Syme (1972) provides an alternative explanation: that it takes a far longer time for social isolation to affect the activity of rats as opposed to mice, quoting Sigg, Day, and Colombo (1966), who found that isolation-induced aggressiveness (which is a behavioral manifestation of the "isolation syndrome" described by Hatch, Wiberg, Zawidzka, Cann, Airth, \& Grice, 1965) develops in mice and rats housed individually for 3 weeks and 3 to 6 months, respectively. Previous studies finding isolates to be more active than group-housed animals have all used

Table 2

Mean Body and Adrenal Weights Obtained After 14 Weeks and 24 Weeks in the Different Cage Conditions (10 Weeks for the Crowded Ss)

\begin{tabular}{|c|c|c|c|c|}
\hline & \multicolumn{3}{|c|}{ Cage Groups } & \multirow[b]{2}{*}{$\mathrm{p}$} \\
\hline & $\begin{array}{l}\text { Isolated } \\
(N=6)\end{array}$ & $\begin{array}{l}\text { Control } \\
(N=6)\end{array}$ & $\begin{array}{c}\text { Crowded } \\
(N=6)\end{array}$ & \\
\hline $\begin{array}{c}\text { Body }(g) \pm S E \\
14 \text { Weeks } \\
24 \text { Weeks }\end{array}$ & $\begin{array}{l}162 \pm 2.95 \\
181 \pm 4.63\end{array}$ & $149 \pm 2.38$ & $179 \pm 2.57$ & $\begin{array}{l}0.05 \\
\text { n.s. }\end{array}$ \\
\hline $\begin{array}{c}\text { Adrenal }(\mathrm{mg}) \\
14 \text { Weeks } \\
24 \text { Weeks }\end{array}$ & $\begin{array}{l}48.16 \pm 2.18 \\
45.17 \pm 1.62\end{array}$ & $39.66 \pm 1.69$ & $40.16 \pm 2.09$ & $\begin{array}{l}0.01 \\
\text { n.s. }\end{array}$ \\
\hline $\begin{array}{c}\text { Adrenal* } \pm S E \\
14 \text { Wecks } \\
24 \text { Weeks }\end{array}$ & $\begin{array}{l}31.62 \pm 1.56 \\
25.07 \pm 1.23\end{array}$ & $27.42 \pm 0.85$ & $22.40 \div 3.34$ & $\begin{array}{l}0.05 \\
\text { n.s. }\end{array}$ \\
\hline
\end{tabular}


mice as Ss (e.g., Essman, 1966: Weltman. Sackler. \& Sparber, 1966). Thus, the results obtained by Syme (1972). who tested isolated and pair-housed rats for 14 consecutive days following weaning, suggest that studies using the two species should not be assumed comparable in terms of the time taken for social caging conditions to affect behavior in a novel test situation such as the open field.

When animals from the control-grouped and isolated housing conditions were tested on the activity platform, this activity difference between isolated and control-grouped animals did not occur, suggesting that locomotor rather than spontaneous or restless motor activity was affected by the lack of stimulation afforded by social isolation. But this argument does not account for activity changes resulting from increasing social density within the cage environment. Rather, it emphasizes the methodological limitations of directly comparing two disparate measures of activity in socially stressed groups which may be interpreted in entirely different ways. The adrenal weight differences illustrate the differing susceptibility of female rats to isolation (Hatch et al, 1965) and crowding (Christian, 1959). Although the crowded group did not show a significant adrenal response over 10 weeks, these animals exhibited a high degree of activity in the stabilimeter-ty'pe activity platform apparatus (Baumeister, Hawkins, \& Cromwell, 1964). Syme (1971) has shown that crowded females consistently reared more and were immobile less often than were isolated or control-grouped animals in the open field. In accordance with Prescott (1970). this behavior pattern would produce a relatively higher level of restless activity using the activity platform. Therefore. which measure is chosen for housing studies, spontaneous or restless activity (e.g.. Essman. 1966) or locomotor activity (e.g., Archer, 1969), may influence the results obtained.

Body weight differences correspond with those found by Sigg, Day, and Colombo (1966) in that the isolates tended to be heavier than the group-housed rats. Also. as in their study, it was found that it takes a far longer time for isolation to differentially affect the behavior of rats in comparison with mice. Twenty-four weeks after weaning. the isolated rats were more active than were the grouped animals. whereas mice show a similar activity difference the day following weaning (Essman. 1966). As noted earlier, this observation is supported by Syme (1972). who demonstrated that housing studies using the two species should not be assumed comparable in terms of the time taken for cage conditions to influence later behavior.

Replication of the present study would obviously be desirable. with the addition of appropriate controls at 14 and 24 weeks (sec Table 2). However. even with these preliminary results. we may conclude that unless social density studies impose housing conditions at an identical age and use the same measure of activity. direct comparison between results obtained should nol be considered.

\section{REFERENCES}

Archer. J. Contrasting effects of group housing and isolation on subsequent open field exploration in laboratory rats. Psychonomic Science. 1969. 14. 234-235.

Archer. J. Effects of pcpulation density on behaviour in rodents. In J. H. Crook (Ed.). Social behaviour in birds and mammals. Essal's on the social ethology of animals and man. London: Academic Press, 1970.

Barnett. S. S. Social stress. In J. O. Carthy and C. L. Duddington (Eds.). Vienpoints in biolog:. Vol. 3. London: Butterworth. 1964.

Baumeister, A.. Hawkins. W. F., \& Cromwell, R. L. Need states and activity level. Psychological Bulletin. 1964, 61, 438-453.

Bronfenbrenner, U. Early deprivation in mammals: A cross-species analysis. In G. Newton and S. Levine (Eds.). Early experience and behavior. Springfield, Ill: Thomas. 1968.

Christian. J. J. The roles of endocrine and behavioral factors in the growth of mammalian populations. In A. Gorbman and $\mathrm{H}$. A. Burne (Eds.), Comparative endocrinologn: New York: Wiley, 1959.

Essman. W. B. The development of activity differences in isolated and aggregated mice. Animal Behaviour. 1966. 14. 406-409.

Hatch, A. M.. Wiberg. G. S., Zawidzka. Z., Cann. M.. Airth. I. II., \& Grice, H. C. Isolation syndrome in the rat. Toxicolog! \& Applied Pharmacology. 1965. 7.737-745.

Kinnard. W. J., \& Watzman. X. Techniques used in the evaluation of psychotropic drugs on animal activity. Journal of Pharmaceutical Sciences, 1966. 55. 995-1012.

Mover, K. E.. \& Kom, J. H. Behavioral effects of isolation in the rat. Psychonomic Science. 1965, 3. 503-504.

Prescott. R. G. W. Some behavioural effects of variables which influence the 'general level of activity' of rats. Animal Behaviour. 1970.18.791-796.

Schnürer. L.-B. Maternal and fortal tesponses to chronic stress in pregnancy. A study in albino rats. Acta Endocrinologica. 1963. Suppl. 80, 1-96.

Sigg. E. B.. Day, C.. \& Colombo. C. Endocrine factors in isolation-induced aggressiveness in rodents. Endocrinolog?. 1965, 78, 679-684.

Stern. J. A.. Winokur. G.. Eisenstein. A.. Tậlor. R.. \& Sly. M. The effect of group vs. individual housing on behavior and physiological responses to stress in the albino rat. Journal of Psychosomatic Research, 1960, 4. 185-190.

S! me, 1.. A. Effects of caging on the behaviour of rats in the open field. Lnpublished master's thesis. Lniversity of Canterhury. 1971.

Syme, L. A.. \& Hughes, R. N. Social isolation in young rats: Effects of cage size on open-field behavior. Psychonomic Science, 1972, 29, 25-26.

Syme. L. A.. \& Syme, G. J. Effects of lithium chloride on the activity of rats tested alone or in pairs. Psychopharmacologia (Berlin). in press.

Welman. A. S.. Sackler. A. M.. \& Sparber. S. B. Endocrine. matabolic and behavioral aspects of isolation itresi on femali alhino mice. Aerospace Medicine, 1966, 37, 804-810.

Winer. B. I. Statistical principles in experimental design. Jin York: McGraw-Hill. 1962.

\section{NOTE}

1. Syme. I. A. Spurious specis comparisons in housing studics using laboratory rats and mice. Cnpublislicd mumbiript. 1972 .

2. Vew Zealand black and white stain.
IRarlsed for publication Siptember 11. 10-2:

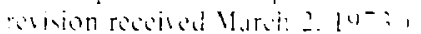

